\section{The Effects of Minerals, Ascorbic Acid, and Salicylic Acid on the Bunch Quality of Tomatoes (Solanum lycopersicum) at High and Low Temperatures}

\author{
Hakan Aktas', Derya Bayındır, Tuba Dilmaçünal, and M. Ali Koyuncu \\ Department of Horticulture, Faculty of Agriculture, University of Suleyman \\ Demirel, 32040 Isparta, Turkey
}

Additional index words. Bunch tomatoes, abscission, ascorbic acid, salicylic acid, minerals, fruit removal force, ethylene, respiration, Solanum lycopersicum

\begin{abstract}
Harvested bunch tomatoes are sensitive to fruit abscission and desiccation of calyxes, which limit product marketability. Our investigation showed that tomato fruit bunches when submitted to a combination of temperature, aqueous solutions and storage time, fruit abscission, and calyx desiccation can be prevented. The loss of fruit weight, the force required to separate the fruit from the calyxes, the respiration rate and ethylene production of the calyxes, the color of the calyxes, and the wilting and desiccation of the calyxes were measured. These results demonstrated that treatment of bunches with supplemented mineral water delays fruit abscission and calyx desiccation and improves the fresh appearance of calyxes during storage.
\end{abstract}

Ecological and geographical conditions allow the production of high-quality tomatoes in large quantities throughout the year in countries such as Turkey that store and export fresh fruit. The tomato crop in Turkey is valued at $\$ 3.7$ billion U.S. (Sarısaçli, 2010), making it one of the leading producers of tomato in the world (Anonymous, 2009).

As a climacteric fruit, tomato has a relatively short postharvest shelf life and many processes affect its quality after harvest. Transpiration, postharvest diseases, advanced ripening, and senescence impact the quality of harvested tomato fruit, particularly after storage (Ali et al., 2010).

Tomatoes harvested as bunches have a fresh appearance, an advantage in the marketplace. Because multiple fruit are picked simultaneously, harvesting tomato bunches reduces harvesting time and labor costs. However, these advantages are reduced when abscission of the fruit and desiccation of the stems and calyx shorten the marketable shelf life of the fruit bunches (Beno-Moualem et al., 2004). After harvest, unlike single tomatoes, the end of the shelf life of bunch tomatoes is determined by the separation of the fruit from the bunch (Lichter et al., 2006). Most of the previous work has been concerned with the shelf life quality of tomato fruit harvested without maintaining the integrity of the fruit bunches (Beno-Moualem et al., 2004; Lichter

Received for publication 22 May 2012. Accepted for publication 9 Aug. 2012.

The authors are thankful to Dr. Ann L.T. Powell (University of California, Department of Plant Science, Davis, US) for her thorough review of the manuscript and her useful advice.

${ }^{1}$ To whom reprint requests should be addressed; e-mail aktashakan33@gmail.com. et al., 2006; Pila et al., 2010). The appearance of the calyx is an important aspect of the fresh appearance of tomato bunches, but little information has been available about what maintains the fresh appearance and quality of the calyxes of tomato. The brightness of the calyx is considered to be an important external indicator of fruit quality, and the appearance of the fruit and calyx influences consumer preferences.

The aim of this study was to determine the interactive effects of two temperatures, three levels of aqueous solutions, and five storage time periods on bunch freshness and the frequency of fruit abscission during storage.

\section{Materials and Methods}

Plant material and growth conditions. Tomato plants (Solanum lycopersicum L. cv. Bandita) were grown on a hanging-carrying system with high wire support training in cocopeat media. Bunches were hand-harvested at the fifth bunch according to a commercial agronomic management. Each tomato bunch contained five or six tomato fruits, from which the proximal pair was at the light-red stage.

Tomato fruit bunches were hand-harvested on 15 Apr. 2010 early in the morning and immediately delivered in cardboard boxes to the laboratory for analysis.

Experimental set-up. Harvested bunch tomatoes were kept in cardboard boxes at 10 or $20{ }^{\circ} \mathrm{C}$ at the same relative humidity level $(80 \% \pm 5 \%)$. Each of these two groups was subdivided into three subgroups, which were submitted to three preserving aqueous solutions, and all six combinations were stored during $5,10,15,20$, or $25 \mathrm{~d}$. In this experiment, there were a total of 30 treatments with three replications and a total of 90 experimental units. In the case of the factor preserving aqueous solution, it consisted of three levels (groups). The first group was the untreated control (C). In the second group, the bunches were treated with distilled water (DW). In the third group, the bunches were treated with a mineral water solution (MAS), which contained $1 \%(\mathrm{w} / \mathrm{v})$ potassium nitrate, $0.5 \%(\mathrm{w} / \mathrm{v})$ zinc sulfate, $1 \%(\mathrm{w} / \mathrm{v})$ calcium chloride, $0.1 \%(\mathrm{w} / \mathrm{v})$ boron, $0.2 \%(\mathrm{w} / \mathrm{v})$ copper sulfate, $0.5 \%(\mathrm{w} / \mathrm{v})$ ascorbic acid (an antioxidant), and $0.1 \%(\mathrm{w} / \mathrm{v})$ salicylic acid (an endogenous growth regulator). For both groups DW and MAS, the solutions were applied with a sprayer in equal volume $(30 \mathrm{~mL})$ to each tomato bunch.

Five days after the beginning of treatments, the following variables of study were determined: weights of the bunches, calyx respiration rate and production of ethylene, and color and sensorial attributes as well.

Weight loss. Weight loss was determined by measuring the weights of each bunch of tomato (containing five to six fruits) during the storage period $(5,10,15,20$, or $25 \mathrm{~d})$ with electronic balance, which is sensitive to $0.01 \mathrm{~g}$ (Scaltec SBA51). The results obtained are expressed as percent weight loss and were calculated by the following formula:

$$
\begin{aligned}
& \text { Loss of weight }(\%) \\
& =[(\text { Initial weight-Period weight }) / \\
& \quad \text { Initial weight }] \times 100
\end{aligned}
$$

Fruit removal force. The force required to remove fruit from the bunch was a measure of the strength of calyxes. The force was measured during the storage period using a Lloyd Instrument LF Plus (Ametek, U.K.) texture machine and software from Nexygen (Version 4.1). A 50-Newton (N) load cell with a constant speed of $100 \mathrm{~mm} \cdot \mathrm{min}^{-1}$ was used. Each replication consisted of three bunches and measurements were made for each fruit in a bunch. The results are expressed in Newtons.

Respiration rate and ethylene production of calyxes. The respiration rates and the production of ethylene by the calyxes in a bunch were determined during the storage period. Calyxes varying from 2.5 to $3.0 \mathrm{~g}$ were placed in airtight glass jars for $24 \mathrm{~h}$ at $20{ }^{\circ} \mathrm{C}$. Measurements of the respiratory rates and the amounts of ethylene produced were made by gas chromatography (GC) using 15 - to $20-\mathrm{mL}$ samples of the head space. Respiration rate and ethylene production are indicated as $\mathrm{mL}$ $\mathrm{CO}_{2} \mathrm{~kg}^{-1} \mathrm{~h}^{-1}$ and $\mu \mathrm{L} \mathrm{kg}^{-1} \mathrm{~h}^{-1}$, respectively. Measurements with an Agilent GC-6890N model gas chromatograph and Chemstation A.09.03 [1417] software were made in the $\mathrm{S} / \mathrm{SL}$ inlet in split mode with a gas sampling valve with $1-\mathrm{mL}$ gas sample by using a fused silica capillary columns (GS-GASPRO, $30 \mathrm{~m} \times 0.32 \mathrm{~mm}$ I.D.) with a thermal conductivity detector (TCD) for respiration rate measurements and flame ionization detector (FID) for ethylene production measurements. Carrier gas flow was $1.7 \mathrm{~mL} \cdot \mathrm{min}^{-1}$ in stable flow mode. The temperature of the oven, the TCD, and the FID detectors were $40{ }^{\circ} \mathrm{C}$ (isothermal), $250{ }^{\circ} \mathrm{C}$, and $250{ }^{\circ} \mathrm{C}$, respectively. 
The color of calyxes. Color calyx was determined using a Minolta CR-300 (Minolta, Ramsey, NJ) color apparatus to measure CIE L* (brightness-darkness), a* ( $+\mathrm{a}^{*}$ : red, $-a^{*}$ : green) and $b^{*}\left(+b^{*}\right.$ : yellow, $-b^{*}$ : blue). Color measurements were performed at three points on both the top and bottom surfaces of the fruit calyxes. The data are expressed as the mean value of both surfaces. The Minolta color measurement apparatus was calibrated according to the standard white plate from the same manufacturer $(\mathrm{Y}=92.3, \mathrm{x}=0.3136$, and $y=0.3194)$. The chroma and hue values were calculated on the basis of the following formula:

$$
\mathrm{h}^{\circ}=\tan ^{-1}\left(\mathrm{~b}^{*} / \mathrm{a}^{*}\right) \quad \text { Chroma }=\sqrt{\left(a^{*}\right)^{2}+\left(b^{*}\right)^{2}}
$$

Sensory evaluation of calyxes. A panel of 15 trained judges evaluated the sensory quality of tomato bunches. Wilting and drying were valued according to a scale from 0 to 4 , where: $0=$ healthy calyxes, $1=$ slight, $2=$ mild, $3=$ severe, $4=$ very severe.

Statistical analysis. Treatments in this experiment were arranged according to a split-split plot experimental design with three replications. The differences between the means of the groups were determined by Tukey's test. All analyses were performed with SPSS software package Version 18.0 (SPSS Inc., Chicago, IL) for Windows by General Linear Model univariate test.

\section{Results and Discussion}

Weight loss. Weight loss above $5 \%$ is a limiting factor for the postharvest life of fruit crops. Weight loss in fruit is known to be related to temperature and storage time (Rao et al., 2011). Weight loss of tomato bunches was affected by the interaction of temperature $\times$ solution $(P<0.05)$ and temperature $\times$ storage time $(P<0.01)$ (Table 1$)$. The interaction temperature $\times$ solution showed that the lowest weight loss was obtained in tomato bunches kept at $10{ }^{\circ} \mathrm{C}$ and sprayed with distilled water, whereas the highest weight loss was obtained in tomato bunches kept at $20^{\circ} \mathrm{C}$ and sprayed with distilled water. Regarding the interaction temperature $\times$ storage time, tomato bunches had the lowest weight loss when kept at $10{ }^{\circ} \mathrm{C}$ and stored for $5 \mathrm{~d}$, whereas the highest weight loss was determined in those tomato bunches kept at $20{ }^{\circ} \mathrm{C}$ and stored during $25 \mathrm{~d}$ (Fig. 1). Fresh fruit weight of tomato bunches kept at $10{ }^{\circ} \mathrm{C}$ was higher than that of fruits kept at $20^{\circ} \mathrm{C}$.

Our results are in agreement with Javanmardi and Kubota (2006) who reported that weight losses of tomatoes stored at room temperature were significantly greater than those stored at low temperature. Increased weight loss resulting from desiccation is not likely in our experiments because the ambient humidity was identical at both storage temperatures and conditions. It is possible that increased metabolic activity (such as breakdown of sugar and protein at the higher temperature) could contribute to the loss of weight at $20^{\circ} \mathrm{C}$ (Rao et al., 2011).

Fruit removal force. The force needed to separate fruit from the calyxes in the bunches was used to determine the strength of the calyxes and infer resistance to abscission. In this experiment, the fruit removal force was significantly affected by the interactions temperature $\times$ solution $(P<0.01)$ and solution $\times$ storage time $(P<0.01)$ (Table 1$)$. Regarding the interaction temperature $\times$ solution, the strongest fruit removal force was obtained in the combination of $10{ }^{\circ} \mathrm{C}$ and MAS (Fig. 2A). The fruit removal force in fruits belonging to bunches stored at $10^{\circ} \mathrm{C}$, treated with MAS,

Table 1. Analysis of variance of weight loss of bunches, fruit removal force, respiration rate, and ethylene production of calyxes, calyx color $\left(\mathrm{L}^{*}, \mathrm{C}^{*}, \mathrm{~h}^{\circ}\right)$, and wilting and drying of calyxes of tomatoes as affected by temperature, solution, and storage time.

\begin{tabular}{|c|c|c|c|c|c|c|c|c|c|c|}
\hline \multicolumn{3}{|c|}{ Treatments } & \multirow[b]{2}{*}{ Wt loss } & \multirow{2}{*}{$\begin{array}{l}\text { Fruit removal } \\
\text { force }\end{array}$} & \multirow{2}{*}{$\begin{array}{l}\text { Respiration } \\
\text { rate }\end{array}$} & \multirow{2}{*}{$\begin{array}{l}\text { Ethylene } \\
\text { production }\end{array}$} & \multicolumn{3}{|c|}{ Color of calxyes } & \multirow[b]{2}{*}{ Wilting and drying } \\
\hline Temperature & Solution & Storage time & & & & & $\mathrm{L}^{*}$ & $\mathrm{C}^{*}$ & $\mathrm{~h}^{\circ}$ & \\
\hline \multirow[t]{15}{*}{$10^{\circ} \mathrm{C}$} & Control & 5 & 0.7 & 9.4 & 0.21 & 10.28 & 36 & 20 & 116 & 1.25 \\
\hline & & 10 & 1.5 & 10.8 & 0.15 & 11.03 & 36 & 23 & 119 & 2.17 \\
\hline & & 15 & 2.2 & 10.3 & 0.50 & 12.73 & 31 & 14 & 115 & 2.50 \\
\hline & & 20 & 2.8 & 5.5 & 0.57 & 12.89 & 35 & 17 & 113 & 2.88 \\
\hline & & 25 & 3.4 & 5.7 & 0.38 & 13.11 & 37 & 19 & 110 & 3.75 \\
\hline & Distilled water & 5 & 0.5 & 10.1 & 0.25 & 7.39 & 37 & 16 & 118 & 1.50 \\
\hline & & 10 & 1.0 & 12.5 & 0.19 & 11.83 & 35 & 22 & 117 & 2.50 \\
\hline & & 15 & 1.3 & 11.2 & 0.60 & 7.01 & 35 & 14 & 106 & 2.13 \\
\hline & & 20 & 1.8 & 9.1 & 0.23 & 9.98 & 38 & 16 & 106 & 2.50 \\
\hline & & 25 & 2.0 & 10.0 & 0.54 & 7.31 & 34 & 16 & 112 & 3.25 \\
\hline & MAS & 5 & 0.8 & 8.6 & 0.28 & 16.70 & 33 & 19 & 113 & 0.50 \\
\hline & & 10 & 1.8 & 13.2 & 0.23 & 13.08 & 33 & 18 & 114 & 1.00 \\
\hline & & 15 & 2.1 & 11.7 & 0.55 & 12.21 & 35 & 15 & 112 & 1.88 \\
\hline & & 20 & 2.2 & 12.3 & 0.22 & 11.76 & 38 & 19 & 115 & 2.25 \\
\hline & & 25 & 2.6 & 16.9 & 0.69 & 12.87 & 34 & 16 & 117 & 3.13 \\
\hline \multirow[t]{15}{*}{$20^{\circ} \mathrm{C}$} & Control & 5 & 5.5 & 9.1 & 0.45 & 14.75 & 40 & 14 & 112 & 2.00 \\
\hline & & 10 & 9.1 & 14.2 & 0.47 & 19.08 & 38 & 16 & 109 & 2.75 \\
\hline & & 15 & 13.3 & 11.5 & 0.67 & 14.92 & 35 & 17 & 106 & 3.17 \\
\hline & & 20 & 16.5 & 7.5 & 0.54 & 11.34 & 33 & 14 & 105 & 3.50 \\
\hline & & 25 & 20.2 & 7.2 & 0.97 & 14.61 & 36 & 14 & 103 & 4.00 \\
\hline & Distilled water & 5 & 6.7 & 10.4 & 0.41 & 18.23 & 37 & 14 & 114 & 1.75 \\
\hline & & 10 & 11.2 & 9.1 & 0.53 & 23.16 & 36 & 17 & 108 & 2.38 \\
\hline & & 15 & 16.0 & 7.7 & 0.54 & 15.11 & 36 & 11 & 104 & 2.67 \\
\hline & & 20 & 19.8 & 8.5 & 0.48 & 14.04 & 39 & 15 & 104 & 3.50 \\
\hline & & 25 & 24.0 & 7.2 & 0.82 & 10.08 & 33 & 14 & 97 & 4.00 \\
\hline & MAS & 5 & 7.4 & 11.0 & 0.81 & 19.33 & 35 & 17 & 112 & 1.33 \\
\hline & & 10 & 11.7 & 12.0 & 0.73 & 30.14 & 35 & 16 & 106 & 2.25 \\
\hline & & 15 & 14.4 & 10.6 & 0.54 & 19.91 & 36 & 15 & 104 & 2.50 \\
\hline & & 20 & 19.2 & 10.7 & 0.48 & 13.46 & 38 & 18 & 104 & 3.00 \\
\hline & & 25 & 23.6 & 10.5 & 0.66 & 14.96 & 35 & 16 & 103 & 3.17 \\
\hline \multicolumn{3}{|l|}{ Temperature } & $* *$ & NS & $* *$ & $* *$ & NS & $* *$ & $* *$ & ** \\
\hline \multicolumn{3}{|l|}{ Solution } & NS & $* *$ & NS & $* *$ & NS & $* *$ & $* *$ & $* *$ \\
\hline \multicolumn{3}{|c|}{ Storage time } & $* *$ & $* *$ & $* *$ & $* *$ & NS & $* *$ & $* *$ & $* *$ \\
\hline \multicolumn{3}{|c|}{ Temperature $\times$ solution } & $*$ & $* *$ & $* *$ & $* *$ & NS & $*$ & NS & NS \\
\hline \multicolumn{3}{|c|}{ Temperature $\times$ storage time } & $* *$ & NS & $*$ & $* *$ & NS & $* *$ & $* *$ & NS \\
\hline \multicolumn{3}{|c|}{ Solution $\times$ storage time } & NS & $* *$ & $* *$ & $* *$ & $* *$ & $* *$ & $* *$ & NS \\
\hline \multicolumn{3}{|c|}{ Temperature $\times$ solution $\times$ storage time } & NS & NS & $* *$ & $* *$ & NS & $* *$ & $* *$ & NS \\
\hline
\end{tabular}

*Five percent; $* * 1 \%$; ns $=$ nonsignificant.

MAS = minerals + ascorbic acid + salicylic acid. 
and stored during $25 \mathrm{~d}$ required $16.9 \mathrm{~N}$ for separation, whereas the control group stored at $10{ }^{\circ} \mathrm{C}$ during $25 \mathrm{~d}$ required $5.7 \mathrm{~N}$ of force. Additionally, this variable was significantly affected by the combination of solution $\times$ storage time, in which the strongest fruit removal force was observed when tomato bunches were treated with the MAS solution and stored during $25 \mathrm{~d}$ (Fig. 2B).

It is well known that additions of calcium, zinc, and boron can increase cell wall rigidity, because these elements have major roles in the structure of the plant cell wall. The mineral composition of the MAS solution included the mineral elements mentioned in the previous paragraph and the treatment application could enhance the stability of the abscission zone cell wall, thereby increasing the force required to separate the calyxes and fruit. Another possibility is that salicylic acid, frequently synthesized in response to stress (Bari and Jones, 2009; Dempsey et al., 2011), and ascorbic acid, an efficient antioxidant (Karappanapandian and Moon, 2011), could alter the calyx abscission zone. Brescht and Cordasco (2006) reported an interaction between fruit water loss and ripening that promotes abscission zone development in bunch tomatoes.

Respiration rate of calyxes. Metabolic reactions such as respiration and ethylene production are key events in fruit ripening, but metabolic activity can be harmful to the maintenance of fruit quality. These reactions ordinarily increase with increasing temperature. The respiration rate of calyxes expressed as $\mathrm{CO}_{2} \mathrm{~kg}^{-1} \mathrm{~h}^{-1}$ was statistically affected by the interaction of temperature $\times$ solution $\times$ storage time $(P<0.01)$ (Table 1$)$. The lowest respiration rate of calyxes was obtained in calyxes of tomato bunches kept at $10{ }^{\circ} \mathrm{C}$ without any spraying and stored during $10 \mathrm{~d}$. In addition, the respiration rate of calyxes was significant affected by the interaction of temperature and storage time $(P<0.05)$. The lowest respiration was recorded in calyxes from tomato bunches kept at $10{ }^{\circ} \mathrm{C}$ and stored during $20 \mathrm{~d}$ (Fig. 3).

Enzymatic reactions occur more slowly at low temperatures; thereby, fruit shelf life can be extended by storage at reduced temperatures (Bron et al., 2005).

Ethylene production of calyxes. The production of ethylene is associated with abscission and senescence in many parts of the plant. The production of ethylene in calyxes of tomato bunches was significantly affected by the double interaction of temperature $x$ storage time $(P<0.01)$ and the triple interaction of temperature $\times$ solution $\times$ storage time $(P<0.01)$ (Table 1$)$. The interaction of temperature $X$ storage time on ethylene production of calyxes yielded the lowest ethylene production of calyxes in tomato bunches kept at $10{ }^{\circ} \mathrm{C}$ and stored during $15 \mathrm{~d}$ (Fig. 4). On the other hand, the interaction temperature $\times$ solution $\times$ storage time yielded the lowest production of ethylene in calyxes of tomato bunches kept at $10^{\circ} \mathrm{C}$, sprayed with distilled water, and stored during $15 \mathrm{~d}$. As expected, higher levels of ethylene production were seen in calyxes stored

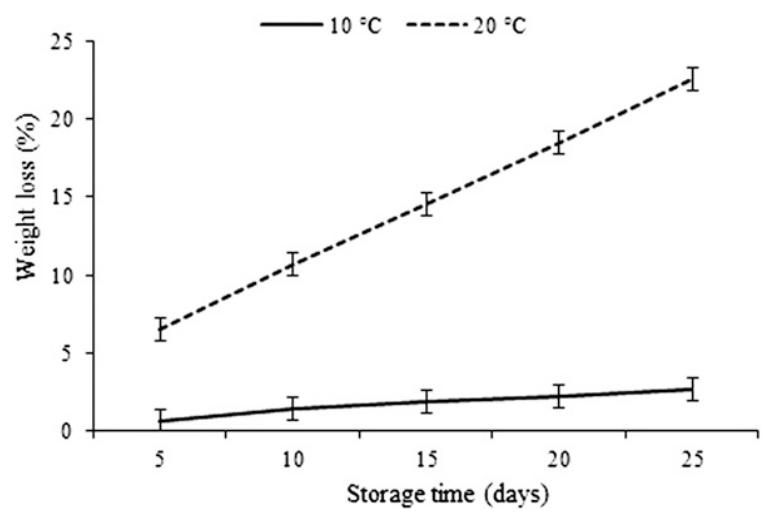

Fig. 1. Effect of the interaction of temperature $\times$ storage time on weight loss of tomato bunches.
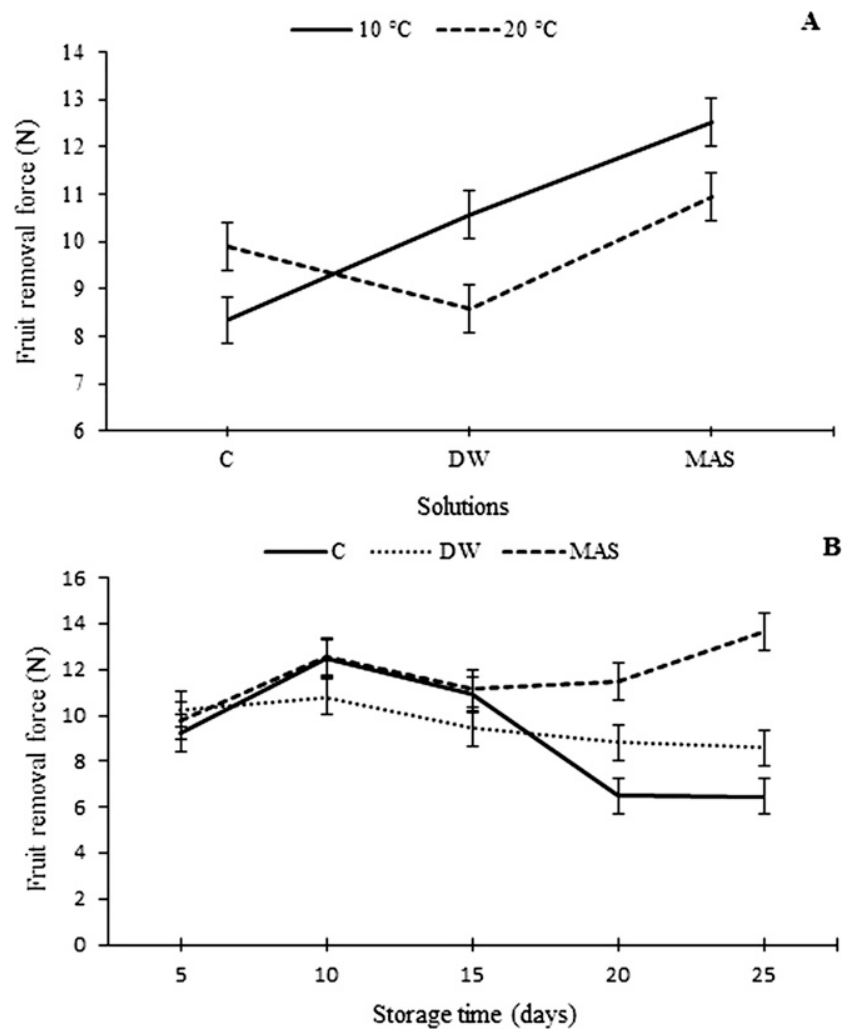

Fig. 2. Effect of the interactions of temperature $\times$ solution $(\mathbf{A})$ and temperature $\times$ storage time $(\mathbf{B})$ on fruit removal force of tomato bunches.

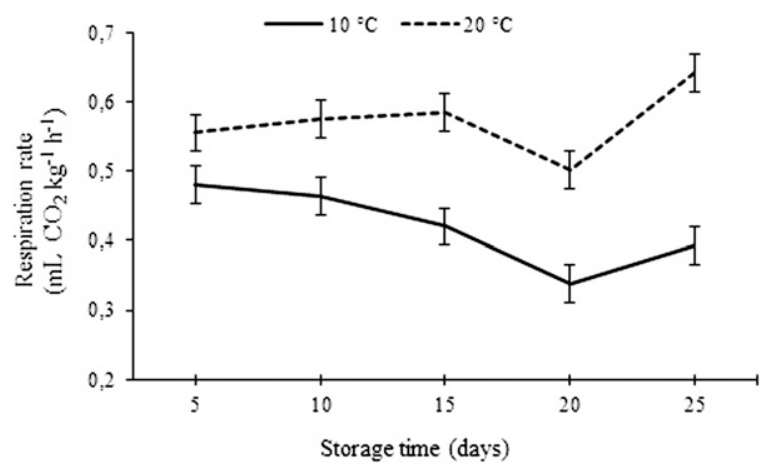

Fig. 3. Effect of the interaction of temperature $\times$ storage time on respiration rate of calyxes. 
at $20{ }^{\circ} \mathrm{C}$ compared with those stored at $10{ }^{\circ} \mathrm{C}$ (Table 1). Similar trends were also reported by Dilmacunal et al. (2011). The effect of ethylene on abscission has been documented in many systems (Lichter et al., 2006; Wang et al., 2002). The maximum production of ethylene by tomato fruit was observed at $25^{\circ} \mathrm{C}$. Ethylene production increased in kiwifruit stored at $35{ }^{\circ} \mathrm{C}$ compared with $17{ }^{\circ} \mathrm{C}$ (Antunes and Sfakiotakis, 2000). Chemicals such as 1-methylcyclopropane (Beno-Moualem et al., 2004), silver thiosulfate, and aminoethoxyvinylgycine block the production and action of ethylene and thereby inhibit tomato fruit abscission (Lichter et al., 2006). Salicylic acid can cause stoma closure, reduce ion uptake and transport, and inhibit ethylene synthesis (Khan et al., 2003), but because neither the DW nor the MAS treatments affected ethylene production in the calyxes in our experiments, the salicylic acid in the MAS treatments may have been insufficient to cause these effects.

The color of calyxes. Appearance of the green color of the calyxes is an important characteristic of tomato fruit bunches. Calyxes that are desiccated as a result of maturity result in the loss of brightness of the green color of the tissue. The color parameters of calyxes were significantly affected by treatments (Table 1). The $\mathrm{L}^{*}$ value represents the degree of lightness. The $\mathrm{L}^{*}$ parameter was affected by the interaction of solution and storage time $(P<0.01)$ (Table 1). As expected, the change in the $\mathrm{L}^{*}$ value during the storage at $10{ }^{\circ} \mathrm{C}$ was less than at $20^{\circ} \mathrm{C}$. The $\mathrm{L}^{*}$ value was altered by DW or MAS treatments. The interaction solution $\times$ storage time had the highest $\mathrm{L}^{*}$ value in calyxes from tomato bunches treated with MAS and stored during $20 \mathrm{~d}$ (Fig. 5).

The chroma parameter of calyx color was affected by the following interactions: temperature $\times$ storage time $(P<0.01)$, solution $\times$ storage time $(P<0.01)$, and temperature $\times$ solution $\times$ storage time $(P<0.01)$ (Table 1$)$. The double interaction temperature $\times$ storage time had the highest chroma value in calyxes from bunches kept at $10^{\circ} \mathrm{C}$ and stored during $10 \mathrm{~d}$ (Fig. 6A), whereas the interaction solution $\times$ storage time had the highest chroma value in calyxes from tomato bunches treated with distilled water and stored during $10 \mathrm{~d}$ (Fig. 6B).

Concerning the triple interaction, the highest chroma value of calyxes from tomato bunches was measured in fruit from bunches kept al $10{ }^{\circ} \mathrm{C}$, treated without any spraying solution, and stored during $10 \mathrm{~d}$.

The hue angle (which is the actual color) was also affected by the following interactions: temperature $\times$ storage time $(P<0.01)$, solution $\times$ storage time $(P<0.01)$, and temperature $\times$ solution $\times$ storage time $(P<$ 0.01) (Table 1).

The double interaction temperature $\times$ storage time had the highest hue value in calyxes from bunches kept at $10^{\circ} \mathrm{C}$ and stored during $10 \mathrm{~d}$ (Fig. 7A), whereas the interaction solution $\times$ storage time had the highest hue value in calyxes from tomato bunches treated with distilled water and stored during $5 \mathrm{~d}$ (Fig. 7B).

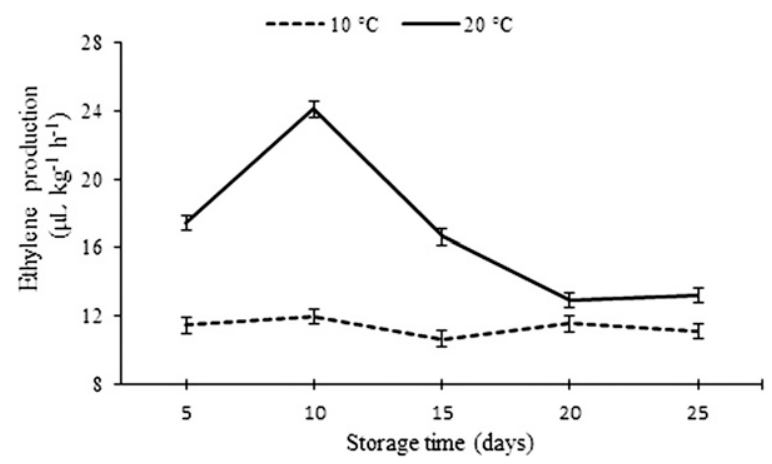

Fig. 4. Effect of the interaction of temperature $\times$ storage time on ethylene production of calyxes.

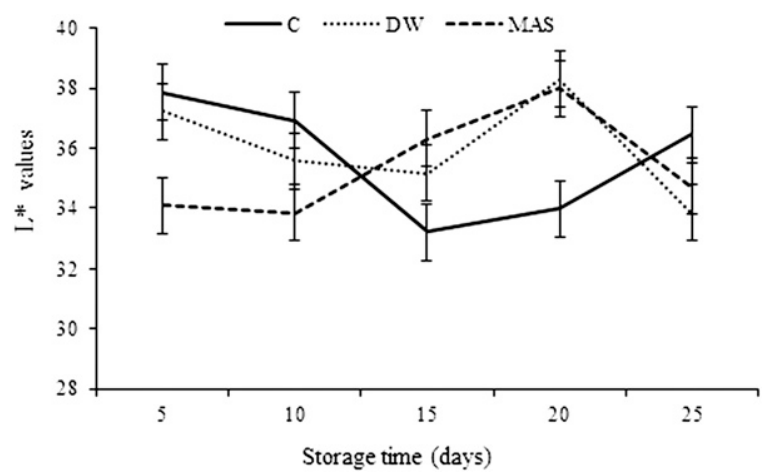

Fig. 5. Effect of the interaction of solution $\times$ storage time on the $\mathrm{L}^{*}$ values of calyxes.
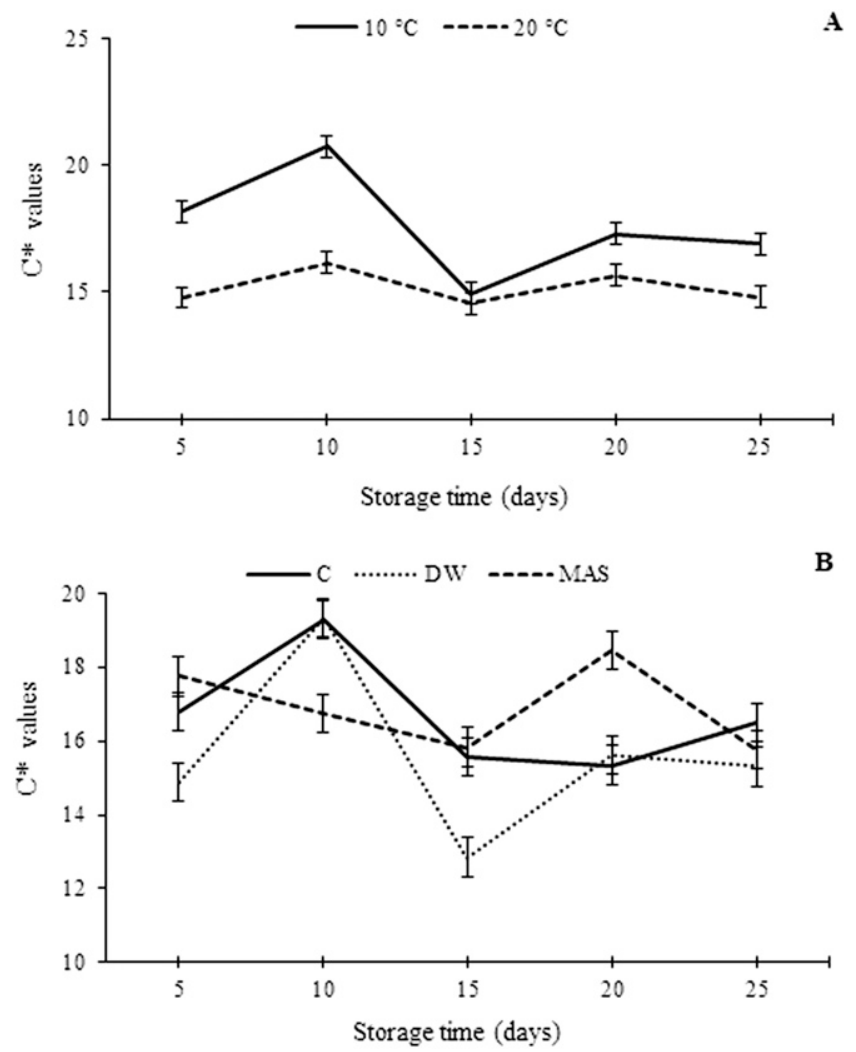

Fig. 6. Effect of the interactions temperature $\times$ storage time $(\mathbf{A})$ and solution $\times$ storage time $(\mathbf{B})$ on $\mathrm{C}^{*}$ values of calyxes. 

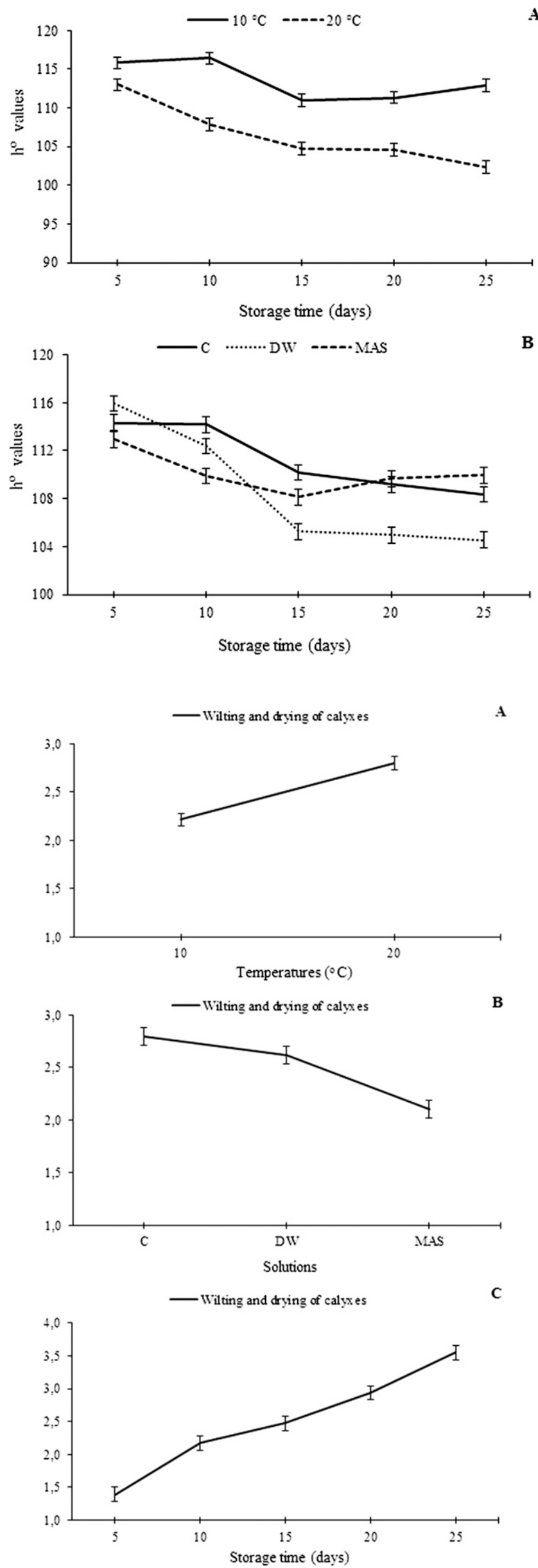

Fig. 7. Effect of the interactions of temperature $\times$ storage time $(\mathbf{A})$ and solution $\times$ storage time (B) on $\mathrm{h}^{\circ}$ values of calyxes.

Fig. 8. Calyxes wilting and drying in response to temperature (A), storage time (B), and solution $(\mathbf{C})$. 


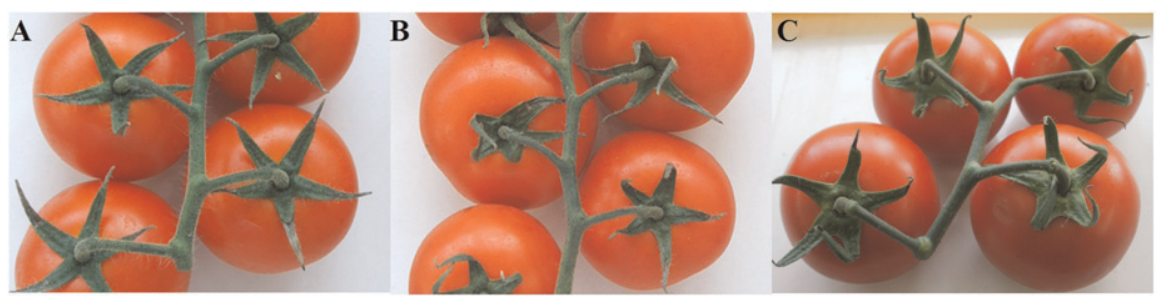

Fig. 9. Bunches of tomato $S$. lycopersicum cv. Bandita after $10 \mathrm{~d}$ at $10{ }^{\circ} \mathrm{C}$. Control (A), distilled water (DW) treated (B), and MAS (mineral water plus $0.5 \%$ ascorbic acid and $0.1 \%$ salicylic acid) treated $(\mathbf{C})$.

Regarding the triple interaction, the highest hue value was measured in calyxes from bunches kept at $10{ }^{\circ} \mathrm{C}$, treated without any spraying solution, and stored during $10 \mathrm{~d}$.

The major chlorophylls are sensitive to heat and light as a result of their long chains of conjugated carbon-carbon double bonds. Chlorophyll degradation may be a cause of decreased $\mathrm{L}^{*}$ and hue values during storage. However, calyxes treated with MAS maintained their hue angle, which may indicate that chlorophyll degradation is reduced by this treatment.

Wilting and drying of calyx. Wilting and desiccation of the calyxes were affected by temperature, solution, and storage time and none of the interactions among treatments was significant (Table 1). Wilting and desiccation increased proportionally to temperature and the calyxes of fruit bunches submitted to $10{ }^{\circ} \mathrm{C}$ had the lowest wilting and drying levels compared with those submitted to $20^{\circ} \mathrm{C}$, as we expected (Fig. 8A). The calyxes of tomato bunches were also affected by the preserving solution factor $(P<0.01)$ (Table $1)$. Calyxes treated with MAS were perceived as having the most reduced wilting and desiccation, whereas those calyxes treated without any solution had the highest wilting and desiccation levels (Fig. 8B). There was a direct proportional relationship between wilting and desiccation and storage time $(P<0.01)$ (Table 1$)$. Thus, the lowest wilting and desiccation was observed in tomato bunches stored during $5 \mathrm{~d}$, whereas the highest wilting and desiccation level was observed in tomato bunches stored during 25 (Fig. 8C). Dvir et al. (2009) reported that water loss has a direct effect on the appearance of the tomato calyx, which becomes full green in color. In this study, the color change of calyxes was determined by measuring $\mathrm{L}^{*}$, chroma, and hue angle variable. MAS treatment of fruit bunches improved the calyx appearance (Fig. 9).

High temperature then enhances the abscission of fruit in bunches. It has been assumed that an increase in temperature causes increased metabolism with a consequent increase in respiration rate and ethylene production. Although increased respiration and ethylene production are associated with the promotion of abscission at the higher temperature, the developmental events that control abscission are largely unknown, although it is well established that they are mediated by ethylene. However, because MAS treatment does not affect respiration or ethylene production but reduces abscission, the treatment with MAS may improve the activity of antioxidants and application of calcium, boron, and zinc minerals in the MAS may improve cell wall rigidity (Aktas et al., 2005, 2006).

Therefore, storage at $10{ }^{\circ} \mathrm{C}$ minimized the quality loses and the tendency of fruit to abscise regardless of the aqueous treatment; storage at $20{ }^{\circ} \mathrm{C}$ caused greater losses in quality and increased tendency for abscission to occur. Treatment with the mineral solution, which contained minerals, ascorbic acid, and salicylic acid (MAS), improved most attributes at both temperatures. MAS treatment was generally better than DW treatment. As a result, the bunches treated with MAS could be stored for up to $20 \mathrm{~d}$ at $10{ }^{\circ} \mathrm{C}$ in good quality, whereas the control group could only be stored up to $10 \mathrm{~d}$ at the same temperature. At $20^{\circ} \mathrm{C}$, the control group could be stored with little loss of quality for up to 5 to $7 \mathrm{~d}$ and MAS doubled the appropriate storage time to $15 \mathrm{~d}$.

\section{Literature Cited}

Aktas, H., K. Abak, L. Ozturk, and I. Cakmak. 2006. Effect of zinc supply on growth and shoot concentrations of sodium and potassium in pepper plants under salinity stress. Turk. J. Agr. For. 30:407-412.

Aktas, H., L. Karni, D.C. Chang, E. Turhan, A. Bar-Tal, and B. Aloni. 2005. The suppression of salinity-associated oxygen radicals production, in pepper (Capsicum annuum L.) fruit, by manganese, zinc and calcium in relation to its sensitivity to Blossom-end Rot. Physiol. Plant. 123:67-74.

Ali, A., M. Maqbool, S. Ramachandran, and P.G. Alderson. 2010. Gum arabic as a novel edible coating for enhancing shelf-life and improving postharvest quality of tomato (Solanum lycopersicum L.) fruit. Postharvest Biol. Technol. 58:42-47.

Anonymous. 2009. Food and Agriculture Organization of the United Nations (FAO). <http:// www.fao.org $>$.
Antunes, M.D.C. and E.M. Sfakiotakis. 2000 Effect of high temperature stress on ethylene biosynthesis, respiration and ripening of 'Hayward' kiwifruit. Postharvest Biol. Technol. 20:251259

Bari, R. and J.D. Jones. 2009. Role of plant hormones in plant defence responses. Plant Mol. Biol. 69:473-488.

Beno-Moualem, D., L. Gusev, O. Dvir, E. Pesis, S. Meir, and A. Lichter. 2004. The effects of ethylene, methyl jasmonate and 1-MCP on abscission of cherry tomatoes from the bunch and expression of endo- $1,4-\beta$-glucanases. Plant Sci. 167:499-507.

Brescht, J.K. and K.M. Cordasco. 2006. Interaction of water loss and fruit ripening promote postharvest cluster tomato fruit abscission. HortScience 41:979.

Bron, I.U., R.V. Ribeiro, F.C. Cavalini, A.P. Jacomino, and M.J. Trevisan. 2005. Temperaturerelated changes in respiration and $\mathrm{Q}_{10}$ coefficient of Guava. Sci. Agr. 62:458-463.

Dempsey, D.A., V. Corina, C.W. Mary, and F.K. Daniel. 2011. Salicylic acid biosynthesis and metabolism. The Arabidopsis Book 9: E0156.

Dilmacunal, T., H. Aktas, M.A. Koyuncu, and D. Bayindir. 2011. The effects of several postharvest treatments on shelf life quality of bunch tomatoes. Not. Bot. Horti. Agrobo. 39:209213.

Dvir, O., I. Farber, M. Rom, A. Rachman, D. BenoMoualem, S. Meir, and A. Lichter. 2009. Low humidity after harvest changes the abscission site in bunch cherry tomatoes. J. Sci. Food Agr. 89:1519-1525.

Javanmardi, J. and C. Kubota. 2006. Variation of lycopene, antioxidant activity, total soluble solids and weight loss of tomato during postharvest storage. Postharvest Biol. Technol. 41:151-155.

Karappanapandian, T. and C.K. Moon. 2011. Reactive oxygen species in plants: Their generation, signal transduction, and scavenging mechanisms. Aust. J. Crop. Sci. 5:709-725.

Khan, W., B. Prithiviraj, and D.L. Smith. 2003. Photosynthetic response of corn and soybean to foliar application of salicylates. J. Plant Physiol. 160:485-492.

Lichter, A., L. Guzev, O. Dvir, I. Farber, A Danshin, E. Pressman, S. Ganzc, and D. Beno-Moualema. 2006. Seasonal changes in the abscission site in bunch tomatoes and differential response to 1-methylcyclopropene. Postharvest Biol. Technol. 40:48-55.

Pila, N., N.B. Gol, and T.V.R. Rao. 2010. Effect of post harvest treatments on physicochemical characteristics and shelf life of tomato (Solanum lycopersicon Mill.) fruits during storage. J. Agr. Environ. Sci. 9:470-479.

Rao, R.T.V., B.G. Neeta, and K.S. Khilana. 2011. Effect of postharverst teatments and storage temperatures on the quality and self-life of sweet pepper (Capsicum annuиm L.). Sci. Hort. 132:18-26.

Sarısaçlı, I.E. 2010. Tomato paste and tomato products. Export Promotion Center of Turkey (IGEME). <http://www.igeme.org.tr/Assets/sip/ tar/tomatoproducts $07>$.

Wang, K.L.C., H. Li, and J.R. Ecker. 2002. Ethylene biosynthesis and signaling networks. Plant Cell 14:131-135. 